Horniker (1937).--Klin. Monatsbl. f. Augenheilk., Vol. XCVIII, p. 478.

KITAHARA (1936).-Klin. Monatsbl. f. Augenheilk., Vol. XCVII, p. 345.

KLINGE (1930).-Virchow's Arch., Vol. CCLXXVIII, p. 438 ; Vol. CCLXXIX, p. 1, etc.

KraUSE, A. K. (1927).-The Evolution of the Tubercle. New York.

LOEWENSTEIN (1926).-Arch. f. Ophthal., Vol. CXVII, p. 130.

(1926).-Tuberkulose des Auges, Text-book: Urban and Schwarzenberg, Vienna.

(1940).-Amer. Jl. Ophthal., November and December.

LUnd, STEFFen (1938).-Acta Ophthal., Vol. XVI, p. 414.

MaWAS (1935).-Bull. Soc. Ophtal. Franç., Vol. XLVIII, p. 379.

REDSLOB (1939).-Ophthalmica, Vol. XCVII, p. 133.

R (1931).-Bull. Soc. Ophtal., Paris, Vol. XLIV, p. 211.

REDSLOB and NORDMAN N (1938). -Bull. Soc. Ophtul. Franc., Vol. LI, p. 533.

Streiff, E. B. (1939).-Klin. Monatsbl. $f$. Augenheilk., Vol. CIII, p. 524.

RumbaUer (1938). -Klin. Monatsbl.f. Augenheilk., Vol. CI, p. 866.

WESSELy (1921).-Münch. Med. Wochenschr., p. 1670.

WEEKERS (1925). -Arch. d'Opht., Vol XLVII, p. 321.

\title{
A CASE OF BLUE SCLEROTICS
}

BY

\section{J. P. SPENCER WALKeR}

HOVE

THIS case of blue sclerotics may be of interest to your readers. The association of deafness and liability to fracture of bones is well known, but there is some doubt as to whether the sclera is thin and so the choroid shows through, or is of normal thickness but transparent.

There was a history of deafness of the left ear of long standing, and of recent fracture of the femur on stepping off an omnibus. As far as she knows, none of her relatives is deaf, has blue sclerotics, or has sustained fractures. The patient was brought to me by her doctor, as she had almost lost the vision of the left eye. On examination the blue sclerotics in both eyes were very noticeable, the vision of the right eye was $6 / 6$, and of the left perception of light only. The tension of the right eye was normal, but that of the left was raised considerably. The field of vision of the right eye was normal. The patient is aged 46 years.

As the tension did not lessen with the use of miotics, I decided to trephine the left eye. Though I expected the sclera might be thin, I was surprised to find how very thin it proved to be. One complete turn of the Elliot's trephine was sufficient to cut through.

My object in reporting this case is not to discuss the treatment of the glaucoma, but to draw attention to the thinness of the sclera, and to the absence of stretching of the sclera with such an increased tension in an eye with so thin an outer coat. . 